\title{
KONSTANTINO JAKOVLEVO-MATECKIO MONOGRAFIJOS „MIESTO KRAŠTOVAIZDŽIO ARCHITEKTÜRA“ TREČIOJO TOMO RECENZIJA
}

\author{
Petras GRECEVIČIUS \\ Architektūros, dizaino ir dailès katedra, Klaipédos universitetas, \\ K. Donelaičio a. 5, LT-92144, Klaipéda, Lietuva \\ El.paštas petras.grecevicius@gmail.com \\ Itteikta 201408 28, priimta 20140910
}

Nuo 2009 metų pirmą kartą mūsų istorijoje miestuose gyvenančių žmonių skaičius viršijo kaimo gyventojų skaičių. Jungtinių Tautų organizacijos duomenimis, 2050 metais urbanizuotose teritorijose gyvens 6,3 milijardo žmonių (United Nations 2009c). Miestų reikšmè šiuolaikinès civilizacijos raidoje nuolat didejja. Tai lemia nemažẻjantis žmonių noras gyventi terpeje, kuri sukuriama ypatingos miesto dvasinès atmosferos, teikiančios geras galimybes kūrybiniam ir profesiniam augimui. Deja, mieste vykstantys procesai šalia teigiamų bruožų turi ir daugybę negatyvių aspektų. Optimalaus, patogaus gyventi, ekologiškai stabilaus miesto struktūros paieška visada buvo ịvairių sričių mokslininkų tyrimų objektu. İvairaus pobūdžio miesto moksliniai tyrimai vykdomi ir Lietuvoje. Tiesa, daugiau išsamesnių publikacijų skirta urbanistikai (K. Šešelgis, V. Jurkštas, A. Miškinis, J. Vanagas, P. Juškevičius, M. Burinskienè, kt.) ir architektūrai (J. Minkevičius, R. Buivydas, A. Samalavičius). Užsienio šalyse jau tvirtai susiformavo trys savarankiškos profesijos - pastatų architektas (building architect), kraštovaizdžio architektas (landscape architect) ir miesto planuotojas (town planner), kurias dar 1968 metais Jungtinių Tautų Tarptautinè darbo organizacija (ILO - International Labour Office) Ženevoje oficialiai pripažino kaip atskiras (IFLA 1982). Ivairaus pobūdžio mokslinių tyrimų medžiaga publikuojama taip pat visose trijose srityse. Lietuvoje kraštovaizdžio architektūros mokslinių studijų, pateiktų monografijos forma, lig šiol nebuvo. Išsamią studiją, skirtą Lietuvos kraštovaizdžio gamtiniam rajonavimui ir ti-

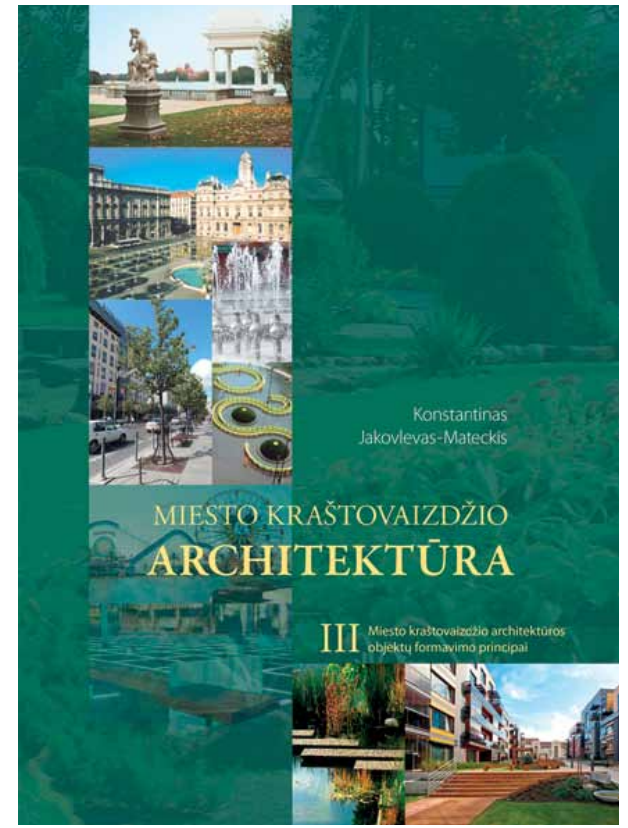

pologijai, 1977 metais parengè geografas A. Basalykas. Atskirose knygose ar mokslinèse studijose įvairūs kraštovaizdžio architektūros teorijos aspektai tyrinèti (V. Stauskas, J. Bučas, kt.), bet mokslinio leidinio, kuriame būtų išsamiau ištyrinèti miesto kraštovaizdžio architektūros formavimo patirtis, metodai, principai, lig šiol nebuvo.

2014 metų pradžioje Vilniaus Gedimino technikos universitete (VGTU) buvo pristatyta architekto K. Jakovlevo-Mateckio knyga, trečiasis monogra- 
fijos „Miesto kraštovaizdžio architektūra“ tomas. Monografiją sudaro trys tomai: pirmasis tomas „Miesto kraštovaizdžio architektūros raida ir teorijos pagrindai“ (2008 m.); antrasis tomas „Želdiniai ir jų komponavimas“ (2003 ir 2010 m.); trečiasis tomas „Miesto kraštovaizdžio architektūros principai“ (2014 m.). Tokio pobūdžio mokslinè monografija parengta ir išleista pirmą kartą. Jau pirmuju dviejų tomų pasirodymas praturtino projektuotoju ir kraštovaizdžio architektūros tyrëjų bibliotekas. Tai pirmas toks didelis ir išsamus mokslo darbas Lietuvoje, skirtas miesto kraštovaizdžio architektūrai. Lietuviškosios kraštovaizdžio architektūros mokyklos (V. Stauskas, G. Daniulaitis, P. Kavaliauskas, P. Grecevičius, J. Bučas, L. Dringelis, I. Daujotaitė, V. Deveikienè, K. Zaleckis, J. KamičaitytèVirbašienè, J. Genys, J. Abromas, G. Stauskis, J. Balkevičius ir kt.) tyrimų kontekste K. JakovlevoMateckio knyga išsiskiria plačiu kompleksišku požiūriu. Tritomis apima beveik visus pagrindinius miesto kraštovaizdžio formavimo segmentus. Na o kiti autoriai mokslinius tyrimus labiau koncentravo ị atskiras kraštovaizdžio architektūros problemas ar objektus. $\mathrm{K}$. Jakovlevas-Mateckis knygoje remdamasis daugelio pasaulio kraštovaizdžio architektūros autoritetų darbais kūrybiškai juos apibendrina ir pateikia metodinius samprotavimus jautriai atsižvelgdamas ị Lietuvos miestų raidos ir struktūros specifiką. Autoriaus moksliniuose samprotavimuose juntama lenkų, rusų bei vokiečių profesionalių kraštovaizdžio mokyklų itaka (W. Czarniecki, J. Bogdanowski, A. Vergunov, Z. Nikolajevskaja, E. Kluckert, kt.). Platesniame tarptautiniame kraštovaizdžio architektūros tyrimų kontekste knyga vertintina kaip svarbus kompleksinis darbas, kuris, jei knyga būtų išleista anglų kalba, neabejotinai taptų vertinga metodine priemone ir kaimyninèse šalyse, Estijoje, Suomijoje, Latvijoje, Baltarusijoje ir kt. Minètose šalyse juntamas tokio pobūdžio publikacijų stygius. Šios srities problemas pasaulyje nagrinejo ir nagrinèja gausus mokslininkų būrys įvairiuose pasaulio regionuose. Ypač reikšmingi amerikiečių darbai (J. O. Simonds, K. Lynch, J. Brookes, M. Laurie, E. Rogers, M. Antrop ir kt.). Pastaruoju metu daug originalių miesto kraštovaizdžio tyrimų atlieka kinų, anglų, japonų, šveicarų, kanadiečių, rusų kraštovaizdžio architektai (C. Steenbergen, kt.). Šiame gausaus mokslinių publikacijų sąrašo kontekste bene labiausiai išsiskiria K. Jakovlevo-Mateckio monografijos dalis, skirta pramonès teritorijų želdynams.

K. Jakovlevo-Mateckio parengto trečiojo tomo pristatymas neįmanomas atsiejant ji nuo anksčiau išleistų pirmojo ir antrojo tomų trumpos charakteristikos. Pirmajame monografijos tome autorius pateikia "miesto kraštovaizdžio“ sampratą, pristato miesto kraštovaizdžio architektūros raidos ir teorijos pagrindus. Nagrinėjamos kraštovaizdžio, kraštovaizdžio architektūros, miesto kraštovaizdžio architektūros sampratos, pagrindinès sąvokos, klasifikavimas, tipai. Pateikiamos miesto kraštovaizdžio formavimo politikos kryptys, principai ir metodologija. Autorius pateikia miesto aplinkos, kaip sudetingos erdvinès ir teritorinès sistemos, kūrimo teorinius metodus ir principus. Reikšminga, kad autorius puikiai sugeba issigilinti i šios specifinès veiklos subtilybes, geba pastebėti architektūros, urbanistikos ir kraštovaizdžio architektūros darnos ryšius, padedančius kurti užbaigtus architektūrinius kūrinius. Miesto kraštovaizdžio architektūros, kaip savarankiškos mokslo ir meno šakos, išskyrimas nesupriešina jos su architektūra, o pademonstruoja, kad kokybiška architektūrinè aplinka galima tik veikiant išvien.

Idomiai ir originaliai atlikta bendroji kraštovaizdžio architektūros raidos analizè. Monografijos autorius, nors ir trumpai, bet sistemingai analizuoja Europos ir Lietuvos miestų, architektūros ir kraštovaizdžio architektūros stilių raidą, apibrež̌damas kraštovaizdžio architektūros vaidmenį, išryškindamas jos planinius erdvinius ypatumus, menines raidos tendencijas ir sąsajas su architektūra bei urbanistika įvairių stilių laikotarpiais.

Autorius ittikinamai pateikia skaitytojui miesto ir kraštovaizdžio gamtinių komponenčių tarpusavio sąveiką, miesto želdynų sistemos reikšmę miesto erdvinei kompozicijai ir raiškai, neapsiribodamas tik teoriniais samprotavimais, bet pateikdamas pagrịstas miesto želdynų urbanistines normas.

Antrajame monografijos tome „Želdiniai ir jų komponavimas" autorius netradiciškai pažvelgè i augalus kraštovaizdyje iš architektūrinių pozicijų. Pateiktos naudingos projektuotojams bendrosios žinios apie sumedejjusius augalus, jų panaudojimą kraštovaizdžio kompozicijose. Analizuojamos medžių, krūmų ir vijoklių dekoratyviosios savybès. Aprašyti svarbiausi kraštovaizdžio architektūros komponentai: vejos, augalai ir jų komponavimo principai. Daug dèmesio skirta gèlynų formavimui. Aprašytos gèlių savybès, įvairių gèlynų tipų komponavimo būdai, pateiktas išsamus rekomenduojamų gèlių katalogas. Gan išsamiai pateikiami rožių komponavimo metodai. Labai svarbu, kad autorius monografijoje pateikia miesto kraštovaizdžiui formuoti atrinktų augalų rūšis remdamasis ne tik kitų autorių publikacijomis, bet ir savo turtinga daugiamečių mokslinių tyrimų bei projektinès veiklos patirtimi.

Trečiuoju monografijos tomu „Miesto kraštovaizdžio architektūros principai“ autorius ne tik logiškai užbaigia miesto kraštovaizdžio teorijos pagrindų pristatymą, bet ir pateikia metodinių rekomendacijų, skir- 
tų kraštovaizdžio moksliniams tyrimams bei praktinei veiklai. Pažymėtina nuosekli ir metodiškai pagrịsta trečiojo tomo struktūra. Ṣ̌ tomą sudaro 10 skyrių. Apimtis 370 puslapių.

Pirmajame skyriuje aptariamos miesto kraštovaizdžio objektų kūrimo problemos. Trumpame Lietuvos kraštovaizdžio formavimo raidos aprašyme K. Jakovlevas-Mateckis įvardija svarbiausius periodus, atkreipia dèmesi j kraštovaizdžiu klasifikavimo būtinybę. Šia tema daug samprotavimu anksčiau pateikè A. Basalykas, V. Stauskas, P. Kavaliauskas, G. Daniulaitis, L. Dringelis, J. Bučas ir kiti mokslininkai, todèl autorius daugiau orientuojasi i miesto kraštovaizdžio tipologijos aprašymą. Moksliniai ir praktiniai kraštovaizdžio tipologijos metodologiniai teiginiai autoriaus pagristi patirtimi, kuri gauta rengiant 2006 metais Lietuvos želdynų klasifikacijos mokslinį darbą kartu su L. Dringeliu ir D. Dimindavičiūte. Pagrindinès miesto želdynų tipologinès grupès pateiktos lentelès forma, kurioje išskirtos dvi želdynų grupès: atskirieji ir priklausomieji. Šiame skyriuje pirmą kartą aprašoma miesto kraštovaizdžio architektū ros objektų - želdynų projektavimo proceso eiga. Svarbus autoriaus teiginys, $\mathrm{kad}$ „miesto sistemoje vienas pagrindinių komponentu yra subjektas (žmogus, bendruomenè)“. Toks požiūris visiškai atitinka ir bendrą pasaulinès kraštovaizdžio architektūros autoritetų požiūrị. Kaip sakydavo pasaulinio garso kraštovaizdžio architektas Eduardas Andrè, „reikia sugebèti patraukti žmogaus dèmesį, sujaudinti sielą. Tai pasiekiama paimant iš gamtos pačius gražiausius vaizdus, formuojant jų harmoniją ir ịvairumą, išryškinant tai, kas joje yra gražaus".

Miesto įvaizdis žmogaus sąmoneje formuojasi iš atskirų svarbių vizualinio ir fizinio poveikio miesto struktūrinių komponentų, iš kurių vieni svarbiausių viešosios erdvès (aikštès, skverai,...). Antrajame skyriuje išsamiai aprašomi miesto erdvių, aikščių, skverų formavimo principai. Miesto viešosioms erdvèms formuoti pastaruoju metu skiriamas didejjantis kraštovaizdžio architektų dèmesys, todèl autoriaus pateikta šių miesto kraštovaizdžio komponentų formavimo raida, optimalių erdvinių parametrų nustatymas yra savalaikis ir reikšmingas.

Pėsčiųjų judejimo mieste organizavimo problemoms spręsti skirtas trečiasis skyrius, kuriame pateikta gan išsami pèsčiųjų zonų ir gatvių integravimo į miesto erdvinę kraštovaizdžio struktūrą metodika. Pradžioje autorius pateikia pesčiujų gatvių ir zonų kūrimosi raidos aprašymą. Čia labai svarbus kritinis tokių miesto elementų europinès patirties vertinimas. Skyriuje pateikiamos konkrečios rekomendacijos pėsčiujų zonoms formuoti. K. Jakovlevas-Mateckis atkreipia demesi i ga- tvės dizaino objektų vaidmeni formuojant kokybišką architektūrinę aplinką. Skyrius užbaigiamas pagrindinių miesto pèsčiųjų gatvių ir zonų projektavimo uždavinių ịvardijimu. Atsakoma ị tokius klausimus, kaip parinkti vietą pésčiųjų gatvei ar zonai, kaip vertinti vietos klimato ypatumus. Autorius pataria „vadovautis teiginiu, kad vienas pagrindinių pèsčiųjų gatvès ar pésčiųjų zonos uždavinių - čia gyvenančių ir lankytojų poreikių tenkinimas". Atkreiptas projektuotojų dèmesys ị tokių zonu lankytoju saugumą, architektūrinès aplinkos dizainą, želdinių kokybę, naktinį apšvietimą, bendruomenès dalyvavimą kūrybiniame procese ir sisteminio požiūrio būtinybę.

Keturi kiti skyriai apima atskirų miesto gyvenamųjų erdvių kraštovaizdžio formavimo problemas, principus ir metodus. K. Jakovlevas-Mateckis analizuodamas miesto parkų tipus, jų sampratą, atkreipia dèmesi í vaikų ir pramoguc parkų stygių Lietuvos miestuose. Autorius išskiria miesto poilsio parkus kaip būtiną aukštos gyvenimo kokybès mieste komponentą, nurodo jų planavimo miesto struktūroje naratyvus bei planavimo principus. Profesionaliai aprašoma centrinio ir kitų miesto poilsio parkų erdvinè struktūra, funkcinès zonos, reikalavimai įejimo zonai ir kt. Skyriuje pateikiami parkų planavimo pavyzdžiai iš ịvairių pasaulio regionų.

Penktajame skyriuje analizuojama miesto istorinių želdynų atkūrimo problema, kritiškai vertinama istorinių sodų, parkų apsaugos, tvarkymo ir atkūrimo teisinès bazès būklè. Autorius pateikia LR Valstybinès kultūros paveldo komisijos $2010 \mathrm{~m}$. lapkričio $26 \mathrm{~d}$. sprendimą „Dèl Lietuvos istorinių parkų ir sodų apsaugos“, kuriame nurodyta: „Lietuvoje 1990-2010 m. neatkurtas nè vienas istorinis želdynas, tačiau esama tik dabartiniu metu restauruojamų parkų atkuriant sunaikintas parkų dalis. Ši veikla vykdoma Užutrakio, Palangos, Verkių, Kuršènų, Taujènų, Šešuolèlių, Aštriosios Kirsnos, Rietavo ir Kurtuvėnų parkuose“. Tokia autoriaus pozicija vertintina kaip pilietiška ir pamokanti. Iš tikro bègant metams Lietuvoje dèl vienokių ar kitokių priežasčių praradome didžiules vertybes. K. Jakovlevas-Mateckis įvardija kaip didelę blogybę nepasvertą kai kurių istorinių parkų privatizavimą dalimis, atkreipia dèmeși ir į nepakankamai kvalifikuotai parengtus labai reikšmingus istorinius želdynus nagrinèjančius dokumentus: „Valstybinès reikšmės parkų nuostatus“, „Valstybinès reikšmės parkų sąrašąa“. Autoriaus nuomone, „istorinių želdynų, tarp jų parkų, vertinimas turi būti tiesiogiai susijęs su laikotarpio kultūriniu tapatumu, su poreikiu išsaugoti ši kultūros paveldo objektą. Istorinio parko atrankos vertinimo procesas turètų prasidèti nuo parko amžiaus 
cenzo ir autentiškumo požymių patikros, nuo meninių parko kraštovaizdžio savybių ir jų vertingumo nustatymo, jo planinès struktūros bei kompozicijos, istorinio meninio stiliaus pagrindinių požymių išryškinimo ir įvertinimo, želdynų ir jų asortimento, komponavimo principu atskleidimo bei įvertinimo ir t. t.“ Autoriaus teiginius akivaizdžiai iliustruoja ir šio meto Lietuvos daugelio istorinių parku apgailètina būklè, o ir tvarkymas dažniausiai vykdomas nekvalifikuotai. E. F. Andrè projektuoto parko Palangoje rekonstrukcija atlikta prastai, darbus vykdè statybos i̇monè, neturinti nei tokio pobūdžio darbų patirties, nei tokio pobūdžio darbams tinkamai paruoštų restauratorių. Skyriuje aprašyta Sereikiškių parko Vilniuje atkūrimo eiga pardemonstravo ir nepakankamą projektuotojų profesionalumą, kai „neleistinai buvo keičiamas A. Strausso parko planas" bei, autoriaus nuomone, padaryta gausybe klaidų. Atviras ir kritiškas autoriaus požiūrio išsakymas yra labai svarbus ateičiai, juo labiau kad kritika pagrindžiama konkrečiais istoriniais faktais, mokslinių tyrimų medžiaga.

Metodiškai svarbūs K. Jakovlevo-Mateckio parengti miesto gyvenamųjų teritorijų sisteminio formavimo metodologiniai principai. Pateiktas gyvenamųjų teritorijų želdynų normavimas, kuris ypač svarbus ne tik planuojant naujus gyvenamuosius kvartalus, bet ir vykdant sovietinių metų formuotų daugiabučių masinès statybos gyvenamųjų rajonų kompleksinę renovaciją. Autorius, pagrindinį demesį skirdamas želdynų formavimui aprašyti, gal kiek mažokai pristato naujausius technologinius sprendimus, kurie susieti su lietaus vandens panaudojimu, vertikaliu želdinimu, sodų ant stogų kūrimu, pastatų vidaus ekologinès būklès pagerinimu. Skyriuje pirmą kartą pateikiami mažaaukščų gyvenamųjų namų sklypų formavimo principai, o tai pastaruoju metu, pletojantis tokiam statybos tipui, igauna vis didesnę reikšmę.

Lietuvos kraštovaizdžio architektūros mokslinèse publikacijose lig šiol nebuvo skiriama dèmesio labai svarbiam miestų gyvenamosios struktūros komponentui - ikimokyklinio ugdymo ịstaigų ir bendrojo lavinimo mokyklų želdynų formavimui, jų aplinkos dizainui. Šiai temai skirtas septintasis skyrius. Aprašomi ne tik želdynų formavimo principai, bet pateikiami ir normatyvai, kurie gali būti naudingi projektuotojams. Autorius parengè tipinę vaikų darželio želdyno suplanavimo schemą, nurodè rekomenduojamų augalų asortimentą, pateike nuodingųjų augalų, draudžiamų sodinti mokyklos teritorijoje, sąrašą.

K. Jakovlevas-Mateckis, daug metų ir kūrybinès energijos skyręs pramonès teritorijų formavimo architektūrai, aplinkos estetikai, aštuntajame monografijos skyriuje apibendrindamas didelę patirti pateike pramonès aplinkos sisteminio formavimo metodologinius principus, pramonės įmonių želdynų formavimo pagrindus. Manau, kad tai ypač svarbi monografijos teorinè ir praktinè dalis, turinti išskirtinę reikšmę Lietuvoje kuriant naujas pramonès įmones ar rekonstruojant esamas. Pastaruoju metu ši sritis ypač apleista. Pramonès i̇monių architektūrai, įmonių teritorijų tvarkymui, ekologizavimui neskiriama reikiamo demesio. Autoriaus pateikta metodika turètų būti taikoma kaip svarbiausia pramoninius objektus projektuojančių specialistų metodinè priemonè. Pramonès įmonių želdinių, smulkiosios architektūros objektų, aplinkos dizaino dalykai turètų būti privalomai architektų, kraštovaizdžio architektų ir urbanistų mokymo programose.

Devintajame skyriuje autorius pristato miesto gatvių, pesčiụjų ir dviračių susisiekimo trasų i̇rengimo, bulvarų ir krantinių želdynų projektavimo principus bei metodus. Miesto gatvès yra svarbūs miesto įvaizdžio struktūros komponentai. Didejjant automobilių srautams miesto gatviu planavimas yra labai atsakingas darbas, reikalaujantis sisteminio vertinimo. Miesto gatvių želdynai, kaip savotiškos želdynų sistemos linijinès jungtys, turi ne tik susisiekimo funkciją, bet ir veikia žmones psichologiškai, todèl jų vaizdo kokybei palaikyti turi būti skiriamas reikiamas demesys. Neprofesionaliai suprojektuoti gatves želdynai gali būti avarijų priežasti$\mathrm{mi}$, taip pat pareikalauti didelių ekonominių investicijų priežiūrai. K. Jakovlevas-Mateckis suformulavo gatvių želdynų projektavimo principus, kurių taikymas užtikrina kokybišką gatves aplinkos suformavimą ir savito miesto vaizdo, tapatumo išsaugojimą.

Autorius ịvardija pagrindinius gatvių želdynų suplanavimo trūkumus remdamasis Vilniaus miesto pavyzdžiu. Reikšmingas K. Jakovlevo-Mateckio tyrimas, kurị jis atliko rengdamas miesto gatvių želdynų projektavimo reikalavimus ir rekomendacijas. Čia apibūdinta daugiafunkcè želdinių reikšmè, augalų ittaka mikroklimatui, mažinant oro užterštumą. Devintojo skyriaus poskyryje pateikiama gatvių želdinių sodinimo ir priežiūros teisingumo analize, aptariama žaliosios užstatymo juostos ideja. Autorius detalizuoja šaligatvių formavimo ypatumus, aprašo žaliosios šaligatvio juostos įrengimą, pateikia mažiausio žaliųjų šaligatvio juostų pločio priklausomybès nuo želdinių komponavimo sprendinio lentelę. Miestų teritorijos, esančios prie intensyvaus eismo A kategorijų gatvių, kenčia nuo triukšmo ir taršos. Šias problemas autorius siūlo spręsti formuojant gatvès triukšmą slopinančių apsauginių želdinių juostas, aprašo ir triukšmui slopinti naudojamas kietąsias priemones: akustines sieneles, iškasas, pylimus ir kt. 
Pastaruoju metu miestų teritorinėse struktūrose praktiškai neformuojami bulvarai, alejos, kurie gali būti svarbiu miesto tapatumo požymiu. K. JakovlevasMateckis aprašo bulvarų formavimo technines charakteristikas, nurodo augalų rūšis, kurias tikslinga naudoti formuojant tokio pobūdžio linijinius želdynus. Lietuvos miestų teritorinèse struktūrose svarbų vaidmeni atlieka marios, upès ar ežerai, todèl monografijoje pateikti krantinių ir želdynu jose irrengimo galimi sprendimai pasitarnaus praktinejje veikloje rengiant atitinkamus projektus.

Paskutiniame skyriuje analizuojama miesto rekreacinių teritorijų kūrimo problema. Kai kurios šiame skyriuje aptariamos problemos nutolsta nuo bendro monografijos konteksto, tokio kaip, pavyzdžiui, Aukštaitijos nacionalinio parko lankytojų apklausos, teikiamų paslaugų analizè ir kt. Nors toks autoriaus požiūris gali būti suprantamas kaip neišvengiamas miesto gyventojų rekreacinių paslaugų sistemos daugiaplaniškumas ir teritorinè sklaida, netelpanti Vilniaus miesto administracinèse ribose.

Visi monografijoje pateiktų kraštovaizdžių raidos, viešųjų erdvių formavimo ir kiti teoriniai teiginiai gausiai iliustruoti kokybiškais paveikslais, schemomis, nuotraukomis. Labai išsamus naudotos literatūros sąrašas. Literatūros sąrašų pateikimas kiekvieno skyriaus pabaigoje padeda skaity tojui geriau palyginti ivairių autorių nuostatas atskirais mokslinio tyrimo klausimais.

Išskirčiau šiuos vertingiausius K. JakovlevoMateckio monografijos bruožus:

1. Monografijos sistemiškumas ir kompleksiškumas apima visą miesto kraštovaizdžio formavimo ciklą, pradedant nuo esamos būklès vertinimo, istoriškumo aspektų, pereinant prie teorinio modeliavimo ir baigiant konkrečiomis rekomendacijomis. Autorius ištisą monografijos tomą skiria vienam svarbiausių kraštovaizdžio komponentų - augalams. Formuojant miesto gèlynus naudingas autoriaus sudarytas originalus 162 rūšių ir veislių gèlių katalogas.

2. Atviras autoriaus ne tik pozityvios, bet ir kritinès nuomonès išsakymas apie konkrečius įvairiu miestų kraštovaizdžių projektus, kraštovaizdžio teisinès bazès netobulumą pagrindžiamas moksline argumentacija. Pavyzdžiui, monografijoje analizuojama Lietuvos istorinių sodų, parkų apsaugos, tvarkymo ir atkūrimo teisinès bazès būklè (121-125 p.), atkreipiamas dèmesys ị nepatenkinamą Lietuvoje dar išlikusių 300 dvarų parkų būklę, analizuojamos netinkamos veiklos priežastys, pateikti konkretūs teisinès bazès tobulinimo siūlymai. Vertinga tai, kad at- kreipiamas dèmesys $\mathfrak{i}$ tarptautinių organizacijų kraštovaizdžio politikos nuostatas, tokias kaip, pavyzdžiui, Jungtinių Tautų švietimo, mokslo ir kultūros organizacijos (UNESCO) svarstomą naują tarptautinį dokumentą „Rekomendacija dèl istorinio urbanistinio kraštovaizdžio išsaugojimo".

3. Atsakingai ir profesionaliai parinkti užsienio ir Lietuvos miestų kraštovaizdžio objektų pavyzdžiai padeda monografijos skaitytojui tikslingiau susiorientuoti didelejje kraštovaizdžio vertybių skalëje. Tokios metodiškai atrinktos vizualinès informacijos pateikimas galès pasitarnauti kraštovaizdžio architektams ir urbanistams rengiant konkrečius miesto kraštovaizdžio projektus. Pažymètina monografijoje aptariamų objektų nuotraukų kokybė, informatyvūs paveikslai, raiški brěžinių grafika.

Tačiau šalia gerųjų monografijos bruožų tenka pastebèti, kad autoriaus siekimas viename leidinyje pateikti kuo išsamesnę labai plačią miesto kraštovaizdžio tematiką neigiamai paveikè kai kurių skyrių kokybę. Manau, kad iš bendro konteksto iškrenta dešimto skyriaus tema „Miesto rekreacinių teritorijų kūrimo problema“. Rekreacinių teritorijų sistemos kūrimą metodiškai tiksliau būtų aptarti knygos pradžioje. Jos atskyrimas nuo miesto visuomeninių erdvių nepageidautinas. Juo labiau kad ketvirtajame skyriuje pristatomi miesto parkai, pagal rangą esantys rekreacinių teritorijų sistemos dalimi. Pasigedau ir daug išsamesnio lietuviškosios kraštovaizdžio architektūros mokyklos pristatymo bei kritinio vertinimo, juo labiau kad ji aukštai vertinama ir tarptautiniame kontekste.

Pastaruoju metu viešojoje mokslinių diskusijų erdveje kai kurių urbanistų (A. Vyšniūnas, 2013) kvestionuota ir kritikuota autoriaus vartojama pamatine sąvoka ,miesto kraštovaizdis“. Kai kurių užsienio ar Lietuvos autorių vartojamos sąvokos: „miestovaizdis“ (angl. townscape ${ }^{1}$ ), , miestiškasis kraštovaizdis“, ,miesto landšaftas“ (angl. urban landscape), „urbanizuotas kraštovaizdis“", kt. (P. Kavaliauskas, 2011). Manau, kad autoriaus pasirinkimas monografijos objektą vadinti „miesto kraštovaizdžio architektūra“ yra gana įtikinamai paaiškintas ir pagrịstas pirmajame monografijos tome (24-28 p.). A. Vyšniūnui daugiausia abejonių kilo dèl kraštovaizdžio sąvokos vartojimo pagrịstumo. Jo nuomone, reiktų vartoti sąvoką „landšaftas“.

\footnotetext{
1 „Townscape“. The character and composition of the built environment including the buildings and the relationships between them, the different types of urban open space, including green spaces, and relationship between buildings and open spaces.
} 
Panašaus pobūdžio diskusijos vyko jau nuo 1965 metų, kai geografas profesorius A. Basalykas pasiūlè vietoje „landšafto“ (vok. landshaft) sąvokos vartoti lietuvišką „kraštovaizdis“. Kai kurie Lietuvos mokslininkai siūle kraštovaizdžiu vadinti regimąją landšafto pusę, t. y. jo vaizdą (V. Stauskas, 1978, P. Gudelis, 1973) ir vartoti abi sąvokas. Šiuo metu Lietuvos Respublikos kraštovaizdžio politikos krypčių apraše teigiama, kad „kraštovaizdis apima visą šalies teritoriją ir erdvę - miestus, miestelius, kaimu vietoves, miškus ir vandenis, daro stiprią įtaką visuomenès gyvenimui ir veiklai, jis yra tautinio identiteto pamatas ir gyvenimo kokybès dalis“. Teisinejje teritorijų planavimo bazeje šiuo metu landšafto sąvoka nevartojama. Europos kraštovaizdžio konvencijos (Žin., 2002, Nr. 104-4621) tekste kraštovaizdžio sąvoka, kuri būtų skirta miestui, nepateikiama. J. Vanagas „Urbanistikos pagrindų“ vadovėlyje vartoja sąvoką ,"miestovaizdis“, kurią ịvardija kaip miestiškojo kraštovaizdžio sudètinį elementą, pasižymintị užstatymo morfotipo, aukštingumo ir architektūrinio įvaizdžio vienove (J. Vanagas, 2008). Užsienio mokslineje literatūroje yra gan didelè sąvokų, ịvardijančių miesto ir kraštovaizdžio jungini, įvairovè. Plačiau vartojama sąvoka Urban Landscape (Clemens Steenbergen, 2008). Apibendrinant galima daryti išvadą, kad „miesto kraštovaizdžio architektūros sąvoka šiandieniniame Lietuvos teisinès aplinkos kontekste yra priimtina ir pateisinama. Tačiau ateityje atsižvelgiant į kraštovaizdžio architektūros teorijos vystymąsi būtų tikslingas sąvokos pakoregavimas pagal IFLA (International Federation of Landscape Architects) nuostatas. Manau, kad logiškiau naudoti townscape ar urban landscape tikslius atitikmenis lietuvių kalboje - „miesto vaizdas“ ar „urbanizuotas (miestiškasis) landšaftas“.

Apibendrinant tenka pažymèti ir autoriaus gebèjimą kalbant apie šiandieninio miesto kraštovaizdi atidžiai remtis istoriškumu, senųjų kultūrų patirtimi. Monografijoje kraštovaizdžio architektūros objektas sklandžiai pristatomas ne tik kaip savarankiškas, bet ir kaip architektūros, urbanistikos, kraštovaizdžio architektūros, aplinkos dizaino integralus objektas. Ši K. Jakovlevo-Mateckio monografija neabejotinai užpildo labai svarbią kraštovaizdžio architektūros mokslo, meninès kūrybos ir praktinès veiklos sritị.

\section{Literatūra}

Čibiras, L.; Jakovlevas-Mateckis, K. 1971. Želdiniai lengvosios pramonès įmoniu teritorijose. Vilnius.

Jakovlevas-Mateckis, K. 2008. Miesto kraštovaizdžio architektūra. 1 tomas, Miesto kraštovaizdžio architektūros raida ir teorijos pagrindai. Vilnius: „Technika“.

Jakovlevas-Mateckis, K. 2003. Miesto kraštovaizdžio architektūra. 2 tomas. Vilnius: „Technika“.
Jakovlevas-Mateckis, K. 2014. Miesto kraštovaizdžio architektūra. 3 tomas, Miesto kraštovaizdžio architektūros objektu formavimo principai. Vilnius: „Technika“.

Burinskienė, M., ir kt. Miestotvarka. 2011. Vilnius: „Technika“.

Kavaliauskas, P. 2011. Kraštovaizdžio samprata ir planavimas: metodinè knyga. Vilnius.

Guidelines for landscape and visual impact assessment. 3rd ed. 2013. Landscape Institute and Environmental Management \& Assessment, USA. 169 p.

World Urbanization Prospects The 2009 Revision [interaktyvus], [žiūrèta $2012 \mathrm{~m}$. gruodžio 20 d.]. Prieiga per internetą: http://esa.un.org/unpd/wup/pdf/WUP2009_Highlights_ Final_R1.pdf 